\title{
MicroRNAs and Cardiovascular Diseases
}

\author{
Koh Ono ${ }^{1,2}$, Yasuhide Kuwabara ${ }^{1}$, and Jiahuai Han² \\ ${ }^{1}$ Department of Cardiovascular Medicine, Graduate School of Medicine, Kyoto University, Kyoto, \\ Japan \\ ${ }^{2}$ Department of Immunology and Microbial Science, The Scripps Research Institute, La Jolla, CA \\ 92037, USA
}

\section{Abstract}

MicroRNAs (miRNAs) are a class of small noncoding RNAs that have gained status as important regulators of gene expression. Recent studies have demonstrated that miRNAs are aberrantly expressed in the cardiovascular system under some pathological conditions. Gain- and loss-offunction studies using in vitro and in vivo models have revealed distinct roles for specific miRNAs in cardiovascular development and physiological function. The implications of miRNAs in cardiovascular disease have recently been recognized, representing the most rapidly evolving research field. In the present article, the currently relevant findings on the role of miRNAs in cardiac diseases will be updated and the target genes of these miRNAs are summarized.

\section{Introduction}

MicroRNAs (miRNAs) are endogenous, single-stranded, small, 22-nucleotide noncoding RNAs. miRNAs are generally regarded as negative regulators of gene expression by inhibiting translation and/or promoting mRNA degradation by base pairing to complementary sequences within the $3^{\prime}$ untranslated region ( $3^{\prime} \mathrm{UTR}$ ) of protein-coding mRNA transcripts [1-3]. However, recent studies have suggested that miR-binding sites are also located in 5' untranslated regions (UTRs) or open reading frames (ORFs), and the mechanism(s) of miR-mediated regulation from these sites has not been defined [4-7]. The first miRNA assigned to a specific function was lin-4, which targets lin-14 during temporal pattern formation in C. elegans [8]. Since then, a variety of miRNAs have been discovered. More than 500 miRNAs have been cloned and sequenced in humans, and the estimated number of miRNA genes is as high as 1,000 in the human genome [9]. Each miRNA regulates dozens to hundreds of distinct target genes, thus miRNAs are estimated to regulate the expression of more than a third of human protein-coding genes [10]. On the other hand, accumulating evidence suggests that miRNAs are regulated by various mechanisms, including epigenetic changes [11]. Thus, the full picture of miRNA-associated regulation is quite complex.

Cardiovascular disease is the leading cause of morbidity and mortality in developed countries. The pathological process of the heart is associated with an altered expression profile of genes that are important for cardiac function. Much of our current understanding of cardiac gene expression indicates that it is controlled at the level of transcriptional regulation, in which transcription factors associate with their regulatory enhancer/promoter sequences to activate gene expression [12]. The regulation of cardiac gene expression is complex, with individual genes controlled by multiple enhancers that direct very specific

Address for correspondence: Koh Ono, MD, PhD, Department of Cardiovascular Medicine, Kyoto University, 54 ShogoinKawaharacho, Sakyo-ku, Kyoto, 606-8507, Japan, Tel: +81-75-751-3190, Fax: +81-75-751-3203, kohono@ kuhp.kyoto-u.ac.jp. 
expression patterns in the heart. miRNAs have reshaped our view of how cardiac gene expression is regulated by adding another layer of regulation at the posttranscriptional level.

The implications of miRNAs in the pathological process of the cardiovascular system have recently been recognized, and research on miRNAs in relation to cardiovascular disease has now become a rapidly evolving field. Here we review the published studies that show the involvement of miRNAs in different aspects of cardiovascular system.

miRNAs have been reviewed recently in several specific systems, including cardiovascular development, cardiac fibrosis, and arrhythmia [13-15]. As is common to all new and rapidly moving fields, it is relatively hard to obtain an overview of the available knowledge from reviews. In this review, we will summarize the current understanding of miRNA function in the heart and outline details of what is known about their putative targets. In addition, we will review several aspects of the regulation of miR expression and their roles in cell signaling that have not been addressed in a cardiovascular context in the accompanying manuscripts $[11,16]$.

\section{Cardiac development}

One approach to study the comprehensive requirements of miRNAs during vertebrate development has been to create mutations in the miRNA processing enzyme Dicer. Several groups disrupted the Dicer gene in mice and reported that the loss of Dicer resulted in embryonic lethality at embryonic day (E)7.5, before body axis formation, due to either a loss of pluripotent stem cells [17] or impaired angiogenesis in the embryo [18]. Dicer1 hypomorphic expression mice also exhibited corpus luteum insufficiency and infertility due to impaired angiogenesis [19]. To understand the role of miRNAs in the developing heart, cardiac-specific deletion of Dicer was generated using Cre recombinase expressed under the control of endogenous $\mathrm{Nkx} 2.5$ regulator elements. Nkx2.5-Cre is active from E8.5, during heart patterning and differentiation, but only after the initial commitment of cardiac progenitors. These embryos showed cardiac failure due to a variety of developmental defects, including pericardial edema and underdevelopment of the ventricular myocardium, which resulted in embryonic lethality at E12.5. These phenotypes are consistent with the defects during heart development observed in zebrafish embryos devoid of Dicer function [20]. It will be important to determine whether Dicer is required for earlier stages of cardiogenesis before E8.5. Dicer activity is also required for normal functioning of the mature heart, as adult mice lacking Dicer in the myocardium have a high incidence of sudden death, cardiac hypertrophy, and reactivation of the fetal cardiac gene program [21].

Recently, Rao et al. generated mice with a muscle-specific deletion of the DiGeorge syndrome critical region gene 8 (DGCR8), which is another component of the miRNA biogenesis pathway, by the use of muscle creatine kinase (MCK)-Cre mice and a conditional floxed allele of the DGCR8 [22]. Since endogenous MCK expression reportedly peaks around birth and declines to $40 \%$ of peak levels by day 10 , these mice can be used to determine the importance of the miRNA pathway in muscle homeostasis. The phenotypic outcome was similar to the cardiac-specific dicer deficient mice, showing a critical role for miRNAs in maintaining cardiac function in mature cardiomyocytes. The authors also reported that miRNA(miR)-1 was quite enriched and accounted for nearly $40 \%$ of all known miRNAs in the adult heart by the deep sequencing of a small RNA library. Since this result is quite different from the reports by others, further experiments using a high-throughput analyzer are required.

Two widely conserved miRNAs that display cardiac- and skeletal-muscle-specific expression during development and in adults are miR-1 and miR-133, which are derived from a common precursor transcript $[23,24]$. miR-1 has been shown to regulate cardiac 
differentiation [23,25-27] and control heart development in mice by regulation of the cardiac transcription factor Hand2 [23]. The importance of miR-1 in cardiogenesis was shown in mice lacking miR-1-2 [26]. Although miR-1-1, which targets the same sequences as miR-1-2, is still expressed in miR-1-2-deficient mice, these mice had a spectrum of abnormalities, including ventricular septal defects in a subset that suffer early lethality, cardiac rhythm disturbances in those that survive, and a striking myocyte cell-cycle abnormality that leads to hyperplasia of the heart with nuclear division persisting postnatally. With regard to miR-133, mice lacking either miR-133a-1 or miR-133a-2 are normal, whereas deletion of both miRNAs causes lethal ventricular-septal defects in approximately half of the double-mutant embryos or neonates [28]. miR-133a double mutant mice that survive to adult succumb to dilated cardiomyopathy and heart failure.

Dysregulation of cell cycle control genes and aberrant activation of the smooth muscle gene program were observed in double-mutant mice, which may be attributable to the upregulation of the miR-133a mRNA targets, Cyclin D2 and serum response factor (SRF).

Previous experiments indicated that miRNAs are broadly important for proper organ development. However, their individual temporal and spatial functions during organogenesis are largely unknown. The heart has been a particularly informative model for such organ patterning, with numerous transcriptional networks that establish chamber-specific gene expression and function [29]. Zebrafish have a two-chambered heart containing a single atrium and ventricle separated by the atrioventricular canal (AVC)[30]. miR-138 is specifically expressed in the ventricular chamber of the zebrafish heart. Temporal-specific knockdown of miR-138 in zebrafish by morpholino and antagomiR led to expansion of AVC gene expression into the ventricular chamber and failure of ventricular cardiomyocytes to fully mature, indicating that miR-138 is required for cardiac maturation and pattering in zebrafish[31]. It is worth noting that miR-138 is required during a discrete developmental window, 24-34 hour post-fertilization. Transcriptional networks that establish chamberspecific gene expression are highly conserved and miR-138 is also conserved across species, ranging from zebrafish to humans, thus, it will also be interesting to determine whether miR-138 plays similar roles in patterning of the mammalian four-chambered heart.

\section{Cardiac hypertrophy}

Because cardiac hypertrophy, an increase in heart size, is associated with nearly all forms of heart failure, it is of clinical importance that we understand the mechanisms responsible for cardiac hypertrophy. It has two forms: 1) physiological, where the heart enlarges in healthy individuals following heavy exercise and is not associated with any cardiac damage, and 2) pathological, where the size of the heart initially increases to compensate for the damage to cardiac tissue, but later on leads to a decline in the left ventricular function [32].

In the model of physiological hypertrophy, only one report has demonstrated that rats subjected to exercise training and transgenic mice with selective cardiac overexpression of a constitutively active mutant of the Akt kinase [33] had reduced levels of the muscle-specific miRNAs, miR-1 and miR-133. In line with this finding, miR-1 and miR-133 were found to be downregulated in the plantaris muscle of mice in response to functional overload [34].

Pathological hypertrophy is mainly caused by hypertension, loss of myocytes following ischemic damage, and genetic alterations that cause cardiomyopathy. Moreover, metabolic abnormality or stress can also lead to hypertrophy [35]. Pathological hypertrophy is the phenotypic endpoint that has been mostly studied in relation to miRNAs of the heart to date. In animal models of cardiac hypertrophy, whole arrays of miRNAs have indicated that separate miRNAs are upregulated, downregulated, or remain unchanged with respect to their levels in a normal heart [36-42]. In these studies, some miRNAs have been more frequently reported as differentially expressed in the same direction than others, indicating the 
possibility that these miRNAs might have common roles in hypertrophy pathogenesis. For example, miR-21, miR-23a, miR-24, miR-125, miR-129, miR-195, miR-199, miR-208, and miR-212 have often been found to be upregualted with hypertrophy, whereas miR-1, miR-133, miR-29, miR-30, and miR-150 have often been found to be downregualted. Interestingly, the forced expression of individual miRNAs, such as miR-23a, miR-23b, miR-24, miR-195, miR-199a, and miR-214, found to be upregulated with cardiac hypertrophy, was sufficient to induce hypertrophic growth. More specifically, miR-195 was sufficient to drive pathological cardiac growth when overexpressed in transgenic mice [36]. Despite the interesting phenotype of these mice, neither targets nor mechanisms underlying miR-195's way of action have been discovered. In contrast to miR-195, in vitro overexpression of miR-150 and miR-181b, which are downregulated in cardiac hypertrophy, resulted in reduced cardiomyocyte cell size [36]. The role of miR-21 in hypertrophy is controversial $[43,44]$. The ability of individual miRNAs to modulate cardiac phenotypes suggests that regulated expression of miRNAs is a cause rather than simply a consequence of cardiac remodeling.

Although the levels of many miRNAs have been demonstrated to be altered in cardiac hypertrophy by a series of high-throughput miRNA microarray analyses, the transcriptional machinery that regulates the expression of miRNAs during cardiac hypertrophy and the molecular mechanisms responsible for individual miRNA-mediated effects on cardiac hypertrophy need to be studied in detail.

Transcriptional regulation of miRNAs is well studied for miR-1/miR-133. SRF is a cardiacenriched transcription factor responsible for the regulation of organized sarcomeres in the heart [45]. SRF interacts synergistically with myocardin to activate miR-1-1 and miR-1-2 by binding to the upstream SRF-binding consensus element known as CArG box [23]. Myocyte enhancer factor 2 (MEF2) also activates transcription of the bicistronic precursor RNA encoding miR-1-2 and miR-133a-1 via an intragenic muscle-specific enhancer [46]. It was reported that nuclear factor of activated T cells isoform 3 (NFATc3), which is welldocumented as playing a key role in mediating the hypertrophic signal of calcineurin, as well as other stimuli [47], regulates the expression of miR-23a. NFATc3 can bind directly to the promoter region of miR-23a and activate its expression, which may convey the hypertrophic signal by suppressing the translation of muscle specific ring finger protein 1 (MuRF1) [48]. It appears that different miRNAs have distinct mechanisms in regulating hypertrophy. miR-1 negatively regulates expression of hypertrophy-associated Calmodulin, MEF2a, and GATA4, and attenuates calcium-dependent signaling through the calcineurinNFAT pathway [49]. miR-133 inhibits hypertrophy through targeting RhoA and Cdc42 [33]. It was reported that targets of miR-208 include thyroid hormone receptor (THR)-associated protein 1 (THRAP1) [50,51], suggesting that miR-208 initiates cardiomyocyte hypertrophy by regulating triiodothyronine-dependent repression of $\beta$-myosin heavy chain (MHC). miR-27a also regulates $\beta$-MHC gene expression by targeting TRbeta 1 in cardiomyocytes[52].

An miRNA may have multiple targets and the current results do not exclude the involvement of any other molecules and/or pathways that can be regulated by miRNAs with reported functions.

\section{Myocardial infarction and cell death}

It is well established that acute myocardial infarction (MI) is a complex process in which multiple genes have been found to be dysregulated [53]. Therefore, it is reasonable to hypothesize that miRNAs could be involved in MI. 
Cardiomyocyte death/apoptosis is a key cellular event in ischemic hearts. Ren et al. applied a mouse model of cardiac ischemia and reperfusion (I/R) in vivo and ex vivo to determine the miRNA expression signature in ischemic hearts, and found that miR-320 expression was consistently dysregulated in ischemic hearts [54]. They identified heat-shock protein 20 (HSP20), a known cardioprotective protein, as a target of for miR-320. Knockdown of endogenous miR-320 provides protection against $\mathrm{I} / \mathrm{R}$-induced cardiomyocyte death and apoptosis by targeting HSP20. The miRNA expression signature in rat hearts at 6 hours after MI revealed that miR-21 expression was significantly downregulated in infracted areas but was upregulated in boarder areas [55]. Adenoviral transfer of miR-21 in vivo decreased cell apoptosis in the border and infracted areas through its target gene, programmed cell death 4 (PDCD4), and activator protein 1 (AP1) pathway.

In vitro experiments showed that miR-1 and miR-133 produced opposing effects on apoptosis induced by oxidative stress in $\mathrm{H} 9 \mathrm{c} 2$ rat ventricular cells, with miR-1 being proapoptotic and miR-133 being anti-apoptotic. Post-transcriptional repression of HSP60 and HSP70 by miR-1 and of caspase- 9 by miR-133 contributes significantly to their opposing actions. miR-1 is also associated with the cell death pathway by inhibiting the translation of insulin like growth factor 1 (IGF)-1 [56,57].

Early ischemia or hypoxia preconditioning is an immediate cellular reaction to brief hypoxia/reoxygenation cycles that involve de novo protein, but not mRNA synthesis [58]. It is described as a mechanism that protects the heart against subsequent prolonged ischemia or I/R induced damage [59]. A recent study by Rane-S et al. revealed a unique function of miR-199a, serving as a molecular switch that triggers an immediate drop in gene expression in response to a decline in oxygen tension, possibly through selective miRNA stability and processing of the stem-loop [60]. They showed that miR-199a directly targets and inhibits translation of hypoxia-inducible-factor (HIF)- $1 \alpha$ and Sirtuin 1 . Hif- $1 \alpha$ regulates hypoxiainduced gene transcription and is regulated by a post-transcriptional oxygen-sensitive mechanism that triggers its prompt expression following a drop in oxygen levels. These results indicate that miR-199a is a master regulator of a hypoxia-triggered pathway and can be utilized for preconditioning cells against hypoxic damage. Since this result demonstrates a functional link between 2 key molecules that regulate hypoxia preconditioning and longevity, it would be of interest to examine the precise regulatory mechanism of miR-199a.

Recent studies have shown that some miRNAs are present in circulating blood and that they are included in exosomes and microparticles [61,62]. The levels of circulating miRNAs have been reported with several disease conditions $[63,64]$. In the cardiovascular diseases, studies on circulating miRNAs have been shown in rat model of myocardial injury [65]. Recently, circulating miRNAs are reported in patients with myocardial infarction [15]. From these results, it has been hypothesized that miRNAs in systemic circulation may reflect tissue damage, and for this reason, they can be used as a biomarker of myocardial infarction [66-68].

\section{Cardiac fibrosis}

Cardiac fibrosis is an important contributor to the development of cardiac dysfunction in diverse pathological conditions, such as MI, ischemic, dilated, and hypertrophic cardiomyopathies, and heart failure and can be defined as an inappropriate accumulation of extracellular matrix (ECM) proteins in the heart [69-74]. Cardiac fibrosis leads to an increased mechanical stiffness, initially causing diastolic dysfunction, and eventually resulting in systolic dysfunction and overt heart failure. In addition, fibrosis causes electrical connection disruption between cardiac myocytes, and hence increases the chance of arrhythmias. Finally, the enhanced diffusion distance for cardiac substrates and oxygen to 
the cardiac myocytes, caused by fibrosis, negatively influences the myocardial balance between energy demand and supply [71,72].

It was shown that the miR-29 family, which is fibroblast enriched, targets mRNAs encoding a multitude of ECM-related proteins involved in fibrosis, including multiple Collagens, Fibrillins, and Elastin [75]. miR-29 is dramatically repressed in the border zone flanking the infracted area in the mouse model of MI. Downregualtion of miR-29 would be predicted to counter the repression of these mRNAs and enhance the fibrotic responses. Therefore, it is tempting to speculate that upregulation of miR-29 may be a therapeutic option for MI.

miR-21 is among the most strongly upregulated miRNAs in response to a variety of forms of cardiac stress $[16,36,75]$. Recently, Thum et al. showed that miR-21 is upregulated in cardiac fibroblasts in the failing heart, where it represses the expression of Sprouty homolog1 (SPRY1), a negative regulator of the extracellular signal-regulated kinase/ mitogen-activated protein (ERK-MAP) kinase signaling pathway [76]. Upregulation of miR-21 in response to cardiac injury was shown to enhance ERK-MAP kinase signaling, leading to fibroblast proliferation and fibrosis. Phosphatase and tensin homologue (PTEN) has also been demonstrated to be a direct target of miR-21 in cardiac fibroblasts [77]. Previous reports characterize PTEN as a suppressor of matrix metalloprotease-2 (MMP-2) expression $[78,79]$. I/R in the heart induced miR-21 in cardiac fibroblasts in the infracted region. Thus, I/R-induced miR-21 limits PTEN function and causes activation of the Akt pathway and increased MMP-2 expression in cardiac fibroblasts.

Connective tissue growth factor (CTGF), a key molecule involved in fibrosis, was shown to be regulated by two miRNAs; miR-133 and miR-30, which are both consistently downregulated in several models of pathological hypertrophy and heart failure. [80]. The authors indicated that miR-133 and miR-30 are downregulated during cardiac disease, which inversely correlates with the upregulation of CTGF. In vitro experiments designed to overexpress or inhibit these miRNAs can effectively repress CTGF expression by interacting directly with the 3'UTR region of CTGF mRNA.

Together, these data indicate that miRNAs are important regulators of cardiac fibrosis and are involved in structural heart disease.

\section{Arrhythmia}

The electrical activities of the heart, the rate and force of contraction of the heart, are orchestrated by multiple categories of ion channels, which are transmembrane proteins that control the movement of ions across the cytoplasmic membrane of cardiomyocytes. Each heartbeat is initiated by a pulse of electrical excitation that begins in a group of specialized pacemaker cells and subsequently spreads throughout the heart. At rest, the membrane is selectively permeable to potassium $\left(\mathrm{K}^{+}\right)$ions, and the electrochemical potential inside the myocyte is negative with respect to the outside. During electrical excitation, the membrane becomes permeable to $\mathrm{Na}^{+}$and the electrochemical potential reverses or depolarizes. Thus, sodium $\left(\mathrm{Na}^{+}\right)$channels determine the rate of membrane depolarization. Connexin $43(\mathrm{Cx} 43)$ is critical for the ventricular gap junction communication, being responsible for inter-cell conduction of excitatory signals. L-type $\mathrm{Ca}^{2+}$ channels are mediators of $\mathrm{Ca}^{2+}$ influx and account for excitation-contraction coupling. L-type $\mathrm{Ca}^{2+}$ channels are located in sarcolemma, including the T-tubes facing the sarcoplasmic reticulum junction, and are activated by membrane depolarization. $I_{\mathrm{caL}}$ is important in heart function because it modulates action potential shape and contributes to pacemaker activities in the sinoatrial and atrioventricular nodal cells. When $\mathrm{K}^{+}$channels open during repolarization, $\mathrm{K}^{+}$exits from the cell because the channels allow the passive movement of ions down their respective concentration gradients. Thus, $\mathrm{K}^{+}$channels govern the membrane potential and the rate of 
membrane repolarization. Pacemaker channels, which carry the non-selective cation currents, are critical in generating sinus rhythm and ectopic heart beats as well. Because the heart beat is so dependent on the proper movement of ions across the surface membrane, disorders of ion channels, or channelopathies, which may result from genetic alterations in ion channel genes or aberrant expression of these genes, can render electrical disturbances predisposing to cardiac arrhythmias [81].

Recently, it was established with luciferase reporter activity and western blot analysis that gap junction protein a1 (GJA1) (encoding connexin43 (Cx43) )and potassium inwardlyrectifying channel, subfamily $\mathrm{J}$, member $2(\mathrm{KCNJ} 2)$ (encoding the $\mathrm{K}+$ channel subunit Kir2.1) are target genes for miR-1 [82]. Cx43 is critical for inter-cell conductance of excitation [83-85], and Kir2.1 governs the cardiac membrane potential [86,87], both of which are important determinants for cardiac excitability. It was shown that miR-1 levels increased in individuals with coronary artery disease, and that when miR-1 is overexpressed in normal and infracted rat hearts, it resulted in slowed conduction velocity and prolonged repolarization excessively and induced PVCs and arrhythmias. On the other hand, blocking miR-1 function with antisense oligoribonucleotides normalized the expression of $\mathrm{Cx} 43$ and Kir2.1, prevented QRS and QT prolongation, and reduced arrhythmias after MI.

Zhao et al. demonstrated that one of the miR-1-2 targets is the cardiac transcription factor Irx5, which represses potassium voltage-gated channel, Shal-related subfamily, member 2 (KCND2), a potassium channel subunit (Kv4.2) responsible for transient outward $\mathrm{K}+$ current (Ito) by use of a targeted deletion technique [26]. The increase in iroquois homeobox 5 (Irx5) and Irx4 protein levels in miR-1-2 mutants corresponded well with a decrease in KCND2 expression. Their study suggests that the combined loss of Irx 5 and Irx 4 disrupts mouse ventricular repolarization with a predisposition to arrhythmias when miR-1 levels are enhanced.

To date, the cardiac ion channel genes that have been confirmed experimentally to be targets of miR-1 or miR-133 include GJA1/Cx43/IJ $[82], \mathrm{KCNJ} 2 / \mathrm{Kir} 2.1 / I_{\mathrm{K} 1}$ [82], potassium voltage-gated channel, subfamily H (eag-related), member 2 (KCNH2)/human ether-à-gogo-related gene $(\mathrm{HERG}) / I_{\mathrm{Kr}}$ [88], potassium voltage-gated channel, KQT-like subfamily, member 1 (KCNQ1)/KvLQT1/I Ks [89], and potassium voltage-gated channel, Isk-related family, member $1(\mathrm{KCNE} 1) / \mathrm{mink} / I_{\mathrm{Ks}}$ [89]. The fact that altered expression of miRNAs can deregulate expression of cardiac ion channels provided novel insight into the molecular understanding of cardiac excitability.

However, considering the inherent capacity of miRNAs to target a broad range of proteins, the link between miR-1 and arrhythmia is far from clear, and more miR-1 targets may be involved. Terentyev et al. investigated the effects of increased expression of miR-1 on excitation contraction coupling and $\mathrm{Ca}^{2+}$ cycling in rat ventricular myocytes using cellular electrophysiology and $\mathrm{Ca}^{2+}$ imaging [90]. They indicated that the protein phosphatase PP2A regulating subunit B56 $\alpha$ is potentially an important target for miR-1 in the heart, and through translational inhibition of this mRNA, miR-1 causes Ca/Calmodulin Kinase II (CaMKII)-dependent hyperphosphorylation of the ryanodine receptor (RyR2), enhances RyR2 activity, and promotes arrythmogenic sarco(endo)plasmic reticulum (SR) $\mathrm{Ca}^{2+}$ release.

Thus, miR-1 may have important pathophysiological functions in the heart, and may be a potential antiarrythmic target. 


\section{Angiogenesis and vascular diseases}

Recently, a few specific miRNAs that regulate endothelial cell functions and angiogenesis have been described. Pro-angiogenic miRNAs include let7f and miR-27b [91], miR-17-92 cluster [92], miR-126 [93,94], miR-130a [95], miR-210, and miR-378, [96,97]. MiRNAs that exert anti-angiogenic effects include miR-15/16 [98,99], miR-20a/b[98], miR-92a [100], and $\mathrm{miR}-221 / 222[101,102]$.

Inflammation is an important part of host defenses against infection and injury, but also contributes to the initiation and progression of atherosclerosis [103], [104]. The response-toinjury hypothesis describes that endothelial dysfunction caused by, for example, elevated low density lipoproteins (LDL), free radicals, hypertension, diabetes mellitus, and/or other factors is an early step in atherosclerosis [103].

Adhesion molecules expressed by activated endothelial cells play a key role in regulating leukocyte trafficking to sites of inflammation. Resting endothelial cells normally do not express adhesion molecules; however, cytokines activate endothelial cells to express adhesion molecules such as vascular cell adhesion molecule 1 (VCAM-1), which mediate leukocyte adherence to endothelial cells. Harris et al. showed that endothelial cells predominantly express miR-126, which inhibits VCAM-1 expression [105]. On the other hand, transfection of endothelial cells with an oligonucleotide that decreases miR-126 permitted an increase in tumor nectrosis factor (TNF)- $\alpha$ stimulated VCAM-1 expression and increased leukocyte adherence to endothelial cells.

Recently, Ji et al. revealed miRNAs that are aberrantly expressed in the vascular walls after balloon injury [106]. Modulating an aberrantly overexpressed miR-21, via antisensemediated depletion, had a significant negative effect on neointimal lesion formation. They also demonstrated that PTEN and Bcl-2 were involved in miR-21-mediated cellular effects. The same group also revealed that miR-221 and miR-222 expression levels were elevated in rat carotid arteries after angioplasty [107]. Moreover, they found that the p27 (Kip1) and p57 (Kip2) were 2 target genes that were involved in miR-221- and miR-222-mediated effects on vascular smooth muscle cells (VSMC) growth. Knockdown of miR-221 and miR-222 resulted in decreased VSMC proliferation both in vitro and in vivo.

Another study demonstrated that the angiotensin II type 1 receptor (AT1R) and miR-155 are coexpressed in endothelial cells and VSMCs, and that miR-155 translationally represses the expression of AT1R [108]. The AT1R gene has been found to be highly polymorphic. In particular, a single nucleotide polymorphism (SNP) has been described in which there is an $\mathrm{A} / \mathrm{C}$ transversion at position 1166 in the $3^{\prime}$-UTR of this gene. The increased frequency of the +1166 allele has been associated with essential hypertension, cardiac hypertrophy and MI [109-111], probably mediated by enhanced AT1R activity. Interestingly, the presence of the +1166 C-allele interrupts base-pairing complementarity within the 3'-UTR of AT1R, and thereby, decreases translational repression of human AT1R by miR-155 [108].

Thus, miR-21, miR-155, miR126, miR-221, and miR-222 might be important modulators of vascular disease and vessel remodeling.

\section{Heart failure}

Since cardiac hypertrophy, fibrosis, arrhythmia, and coronary artery disease can cause heart failure, all of the miRNAs discussed so far are associated with this disease entity.

It is well known that heart failure is characterized by left ventricular remodeling and dilatation associated with activation of a fetal gene program triggering pathological changes in the myocardium associated with progressive dysfunction. Consistent with the reactivation 
of the fetal gene program during heart failure, an impressive similarity has been found between the miRNA expression pattern occurring in human failing hearts and that seen in the hearts of 12-14-week-old fetuses [42]. Indeed, more than about $80 \%$ of the induced and repressed miRNAs were regulated in the same direction in fetal and failing heart tissue compared with the healthy adult control left ventricle tissue. The most consistent changes were upregulation of miR-21, miR-29b, miR-129, miR-210, miR-211, miR-212, and miR-423, with downregulation of miR-30, miR-182, and miR-526. Interestingly, gene expression analysis revealed that most of the upregulated genes were characterized by the presence of a significant number of the predicted binding sites for downregulated miRNAs and vice versa.

Recently, many profiling studies have been conducted and revealed a large number of miRNAs that are differentially expressed in heart failure, pointing to the new mode of regulation of cardiovascular diseases $[2,38,40,41,49,80]$. Horie et al. indicated that miR-133 may fine-tune glucose transporter 4 (GLUT4) via targeting kruppel-like factor-15 (KLF15) in heart failure [112] and there may be many other miRNA functions in specific disease settings. Nishi et al. suggested that four different miRNAs, which have the same seed sequence, regulate mitochondrial membrane potential during the transition from cardiac hypertrophy to failure [113].

miRNA exerts its role in the treatment with chemotherapeutic agent. It is suggested that the up-regulation of miR-146a after Dox treatment is involved in acute Dox-induced cardiotoxicity by targeting ErbB4 [114]. Inhibition of both ErbB2 and ErbB4 signalling may be one of the reasons why those patients who receive concurrent therapy with Dox and trastuzumab suffer from congestive heart failure (CHF).

\section{Metabolic syndrome and cholesterol regulation}

Recent reports have indicated that miR-33 controls cholesterol homeostasis based on knockdown experiments using antisense technology [115-117]. Mir-33 deficient mice were generated and the critical role for miR-33 in the regulation of ATP-binding cassette transporter A1 (ABCA1) expression and high density lipoprotein (HDL) biosynthesis was confirmed in vivo[118].

In humans, sterol regulatory element binding protein 1 (SREBP1) and SREBP2 encode miR-33b and miR-33a, respectively [117]. It is well known that hypertriglycemia in metabolic syndrome is caused by the insulin-induced increase in SREBPIC mRNA and protein levels $[119,120]$. Low HDL often accompanies this situation and it is possible that the reduction in HDL is caused by a decrease in ABCA1, because of the increased production of miR-33b from the insulin-induced induction of SREBPIC. Although it is impossible to prove this in animal models that lack miR-33b, antagonizing miR-33 could be a promising way to raise HDL levels when the transcription of both SREBPs is upregulated. Thus, a combination of silencing of endogenous miR-33 and statins may be a useful therapeutic strategy for raising HDL and lowering LDL levels especially for metabolic syndrome subjects.

The potential binding sites of miRNAs, which are shown in TargetScan (http://www.targetscan.org/), associated with cardiovascular diseases are summarized in the Table 1. Single nucleotide polymorphism (SNP) information is derived from the Single Nucleotide Polymorphism Database (dbSNP, http://www.ncbi.nlm.nih.gov/projects/SNP/ ). All abbreviations are explained in Table 2. 


\section{Summary}

Recent studies provide clear evidence that miRNAs modulate a diverse spectrum of cardiac functions with developmental, pathophysiological, and clinical implications. The biology of miRNAs in cardiovascular disease is a young research area and an emerging field.

Identifying the gene targets and signaling pathways responsible for their cardiovascular effects is critical for future studies.

Taken together, these recent pieces of evidence show that miRNAs play powerful roles in cardiovascular systems and are sure to open the door to previously unappreciated medical therapies.

\section{Acknowledgments}

This work was supported in part by a Grant-in-Aid for Scientific Research from the Ministry of Education, Culture, Sports, Science and Technology of Japan to K. Ono, T. Kita, and T. Kimura, by the Global COE Program "Center for Frontier Medicine" by the Ministry of Education, Culture, Sports, Science, and Technology (MEXT), of Japan to K. Ono, and by NIH grants AI068896 to J. Han.

\section{References}

1. Kiriakidou M, Tan GS, Lamprinaki S, De Planell-Saguer M, Nelson PT, Mourelatos Z. An mRNA m7G cap binding-like motif within human Ago2 represses translation. Cell. 2007; 129:1141-1151. [PubMed: 17524464]

2. Bagga S, Bracht J, Hunter S, Massirer K, Holtz J, Eachus R, Pasquinelli AE. Regulation by let-7 and lin-4 miRNAs results in target mRNA degradation. Cell. 2005; 122:553-563. [PubMed: 16122423]

3. Humphreys DT, Westman BJ, Martin DI, Preiss T. MicroRNAs control translation initiation by inhibiting eukaryotic initiation factor 4E/cap and poly(A) tail function. Proc Natl Acad Sci U S A. 2005; 102:16961-16966. [PubMed: 16287976]

4. Grey F, Tirabassi R, Meyers H, Wu G, McWeeney S, Hook L, Nelson JA. A viral microRNA downregulates multiple cell cycle genes through mRNA 5'UTRs. PLoS Pathog. 2010; 6:e1000967. [PubMed: 20585629]

5. Jopling CL, Yi M, Lancaster AM, Lemon SM, Sarnow P. Modulation of hepatitis C virus RNA abundance by a liver-specific MicroRNA. Science. 2005; 309:1577-1581. [PubMed: 16141076]

6. Tay Y, Zhang J, Thomson AM, Lim B, Rigoutsos I. MicroRNAs to Nanog, Oct4 and Sox 2 coding regions modulate embryonic stem cell differentiation. Nature. 2008; 455:1124-1128. [PubMed: 18806776]

7. Forman JJ, Legesse-Miller A, Coller HA. A search for conserved sequences in coding regions reveals that the let-7 microRNA targets Dicer within its coding sequence. Proc Natl Acad Sci U S A. 2008; 105:14879-14884. [PubMed: 18812516]

8. Wightman B, Ha I, Ruvkun G. Posttranscriptional regulation of the heterochronic gene lin-14 by lin-4 mediates temporal pattern formation in C. elegans. Cell. 1993; 75:855-862. [PubMed: 8252622]

9. Berezikov E, Guryev V, van de Belt J, Wienholds E, Plasterk RH, Cuppen E. Phylogenetic shadowing and computational identification of human microRNA genes. Cell. 2005; 120:21-24. [PubMed: 15652478]

10. Lewis BP, Burge CB, Bartel DP. Conserved seed pairing, often flanked by adenosines, indicates that thousands of human genes are microRNA targets. Cell. 2005; 120:15-20. [PubMed: 15652477]

11. Sato F. Epigenetics and miRNA. FEBS-J. 2011

12. Olson EN. Gene regulatory networks in the evolution and development of the heart. Science. 2006; 313:1922-1927. [PubMed: 17008524] 
13. Liu N, Olson EN. MicroRNA regulatory networks in cardiovascular development. Dev Cell. 2010; 18:510-525. [PubMed: 20412767]

14. Jiang X, Tsitsiou E, Herrick SE, Lindsay MA. MicroRNAs and the regulation of fibrosis. FEBS J. 2010; 277:2015-2021. [PubMed: 20412055]

15. Wang GK, Zhu JQ, Zhang JT, Li Q, Li Y, He J, Qin YW, Jing Q. Circulating microRNA: a novel potential biomarker for early diagnosis of acute myocardial infarction in humans. Eur Heart J. 2010; 31:659-666. [PubMed: 20159880]

16. Ichimura A. miRNAs and regulation of cell signaling. FEBS-J. 2011

17. Bernstein E, Kim SY, Carmell MA, Murchison EP, Alcorn H, Li MZ, Mills AA, Elledge SJ, Anderson KV, Hannon GJ. Dicer is essential for mouse development. Nat Genet. 2003; 35:215217. [PubMed: 14528307]

18. Yang WJ, Yang DD, Na S, Sandusky GE, Zhang Q, Zhao G. Dicer is required for embryonic angiogenesis during mouse development. J Biol Chem. 2005; 280:9330-9335. [PubMed: 15613470]

19. Otsuka M, Zheng M, Hayashi M, Lee JD, Yoshino O, Lin S, Han J. Impaired microRNA processing causes corpus luteum insufficiency and infertility in mice. J Clin Invest. 2008; 118:1944-1954. [PubMed: 18398510]

20. Giraldez AJ, Cinalli RM, Glasner ME, Enright AJ, Thomson JM, Baskerville S, Hammond SM, Bartel DP, Schier AF. MicroRNAs regulate brain morphogenesis in zebrafish. Science. 2005; 308:833-838. [PubMed: 15774722]

21. da Costa Martins PA, Bourajjaj M, Gladka M, Kortland M, van Oort RJ, Pinto YM, Molkentin JD, De Windt LJ. Conditional dicer gene deletion in the postnatal myocardium provokes spontaneous cardiac remodeling. Circulation. 2008; 118:1567-1576. [PubMed: 18809798]

22. Rao PK, Toyama Y, Chiang HR, Gupta S, Bauer M, Medvid R, Reinhardt F, Liao R, Krieger M, Jaenisch R, et al. Loss of cardiac microRNA-mediated regulation leads to dilated cardiomyopathy and heart failure. Circ Res. 2009; 105:585-594. [PubMed: 19679836]

23. Zhao Y, Samal E, Srivastava D. Serum response factor regulates a muscle-specific microRNA that targets Hand 2 during cardiogenesis. Nature. 2005; 436:214-220. [PubMed: 15951802]

24. Chen JF, Mandel EM, Thomson JM, Wu Q, Callis TE, Hammond SM, Conlon FL, Wang DZ. The role of microRNA-1 and microRNA-133 in skeletal muscle proliferation and differentiation. Nat Genet. 2006; 38:228-233. [PubMed: 16380711]

25. Kwon C, Han Z, Olson EN, Srivastava D. MicroRNA1 influences cardiac differentiation in Drosophila and regulates Notch signaling. Proc Natl Acad Sci U S A. 2005; 102:18986-18991. [PubMed: 16357195]

26. Zhao Y, Ransom JF, Li A, Vedantham V, von Drehle M, Muth AN, Tsuchihashi T, McManus MT, Schwartz RJ, Srivastava D. Dysregulation of cardiogenesis, cardiac conduction, and cell cycle in mice lacking miRNA-1-2. Cell. 2007; 129:303-317. [PubMed: 17397913]

27. Niu Z, Li A, Zhang SX, Schwartz RJ. Serum response factor micromanaging cardiogenesis. Curr Opin Cell Biol. 2007; 19:618-627. [PubMed: 18023168]

28. Liu N, Bezprozvannaya S, Williams AH, Qi X, Richardson JA, Bassel-Duby R, Olson EN. microRNA-133a regulates cardiomyocyte proliferation and suppresses smooth muscle gene expression in the heart. Genes Dev. 2008; 22:3242-3254. [PubMed: 19015276]

29. Srivastava D. Making or breaking the heart: from lineage determination to morphogenesis. Cell. 2006; 126:1037-1048. [PubMed: 16990131]

30. Stainier DY. Zebrafish genetics and vertebrate heart formation. Nat Rev Genet. 2001; 2:39-48. [PubMed: 11253067]

31. Morton SU, Scherz PJ, Cordes KR, Ivey KN, Stainier DY, Srivastava D. microRNA-138 modulates cardiac patterning during embryonic development. Proc Natl Acad Sci U S A. 2008; 105:17830-17835. [PubMed: 19004786]

32. Levy D, Garrison RJ, Savage DD, Kannel WB, Castelli WP. Prognostic implications of echocardiographically determined left ventricular mass in the Framingham Heart Study. N Engl J Med. 1990; 322:1561-1566. [PubMed: 2139921] 
33. Care A, Catalucci D, Felicetti F, Bonci D, Addario A, Gallo P, Bang ML, Segnalini P, Gu Y, Dalton ND, et al. MicroRNA-133 controls cardiac hypertrophy. Nat Med. 2007; 13:613-618. [PubMed: 17468766]

34. McCarthy JJ, Esser KA. MicroRNA-1 and microRNA-133a expression are decreased during skeletal muscle hypertrophy. J Appl Physiol. 2007; 102:306-313. [PubMed: 17008435]

35. Rajabi M, Kassiotis C, Razeghi P, Taegtmeyer H. Return to the fetal gene program protects the stressed heart: a strong hypothesis. Heart Fail Rev. 2007; 12:331-343. [PubMed: 17516164]

36. van Rooij E, Sutherland LB, Liu N, Williams AH, McAnally J, Gerard RD, Richardson JA, Olson EN. A signature pattern of stress-responsive microRNAs that can evoke cardiac hypertrophy and heart failure. Proc Natl Acad Sci U S A. 2006; 103:18255-18260. [PubMed: 17108080]

37. Chen JF, Murchison EP, Tang R, Callis TE, Tatsuguchi M, Deng Z, Rojas M, Hammond SM, Schneider MD, Selzman CH, et al. Targeted deletion of Dicer in the heart leads to dilated cardiomyopathy and heart failure. Proc Natl Acad Sci U S A. 2008; 105:2111-2116. [PubMed: 18256189]

38. Cheng Y, Ji R, Yue J, Yang J, Liu X, Chen H, Dean DB, Zhang C. MicroRNAs are aberrantly expressed in hypertrophic heart: do they play a role in cardiac hypertrophy? Am J Pathol. 2007; 170:1831-1840. [PubMed: 17525252]

39. Sayed D, Hong C, Chen IY, Lypowy J, Abdellatif M. MicroRNAs play an essential role in the development of cardiac hypertrophy. Circ Res. 2007; 100:416-424. [PubMed: 17234972]

40. Ikeda S, Kong SW, Lu J, Bisping E, Zhang H, Allen PD, Golub TR, Pieske B, Pu WT. Altered microRNA expression in human heart disease. Physiol Genomics. 2007; 31:367-373. [PubMed: 17712037]

41. Tatsuguchi M, Seok HY, Callis TE, Thomson JM, Chen JF, Newman M, Rojas M, Hammond SM, Wang DZ. Expression of microRNAs is dynamically regulated during cardiomyocyte hypertrophy. J Mol Cell Cardiol. 2007; 42:1137-1141. [PubMed: 17498736]

42. Thum T, Galuppo P, Wolf C, Fiedler J, Kneitz S, van Laake LW, Doevendans PA, Mummery CL, Borlak J, Haverich A, et al. MicroRNAs in the human heart: a clue to fetal gene reprogramming in heart failure. Circulation. 2007; 116:258-267. [PubMed: 17606841]

43. Latronico MV, Catalucci D, Condorelli G. Emerging role of microRNAs in cardiovascular biology. Circ Res. 2007; 101:1225-1236. [PubMed: 18063818]

44. Sayed D, Rane S, Lypowy J, He M, Chen IY, Vashistha H, Yan L, Malhotra A, Vatner D, Abdellatif M. MicroRNA-21 targets Sprouty2 and promotes cellular outgrowths. Mol Biol Cell. 2008; 19:3272-3282. [PubMed: 18508928]

45. Olson EN, Schneider MD. Sizing up the heart: development redux in disease. Genes Dev. 2003; 17:1937-1956. [PubMed: 12893779]

46. Liu N, Williams AH, Kim Y, McAnally J, Bezprozvannaya S, Sutherland LB, Richardson JA, Bassel-Duby R, Olson EN. An intragenic MEF2-dependent enhancer directs muscle-specific expression of microRNAs 1 and 133. Proc Natl Acad Sci U S A. 2007; 104:20844-20849. [PubMed: 18093911]

47. Wilkins BJ, Molkentin JD. Calcium-calcineurin signaling in the regulation of cardiac hypertrophy. Biochem Biophys Res Commun. 2004; 322:1178-1191. [PubMed: 15336966]

48. Lin Z, Murtaza I, Wang K, Jiao J, Gao J, Li PF. miR-23a functions downstream of NFATc3 to regulate cardiac hypertrophy. Proc Natl Acad Sci U S A. 2009; 106:12103-12108. [PubMed: 195744661]

49. Ikeda S, He A, Kong SW, Lu J, Bejar R, Bodyak N, Lee KH, Ma Q, Kang PM, Golub TR, et al. MicroRNA-1 negatively regulates expression of the hypertrophy-associated calmodulin and Mef2a genes. Mol Cell Biol. 2009; 29:2193-2204. [PubMed: 19188439]

50. van Rooij E, Sutherland LB, Qi X, Richardson JA, Hill J, Olson EN. Control of stress-dependent cardiac growth and gene expression by a microRNA. Science. 2007; 316:575-579. [PubMed: 17379774]

51. Callis TE, Pandya K, Seok HY, Tang RH, Tatsuguchi M, Huang ZP, Chen JF, Deng Z, Gunn B, Shumate J, et al. MicroRNA-208a is a regulator of cardiac hypertrophy and conduction in mice. $\mathrm{J}$ Clin Invest. 2009; 119:2772-2786. [PubMed: 19726871] 
52. Nishi H, Ono K, Horie T, Nagao K, Kinoshita M, Kuwabara Y, Watanabe S, Takaya T, Tamaki Y, Takanabe-Mori R, et al. MicroRNA-27a Regulates Beta Cardiac Myosin Heavy Chain Gene Expression by Targeting Thyroid Hormone Receptor \{beta 1 in Neonatal Rat Ventricular Myocytes. Mol Cell Biol. 2011; 31:744-755. [PubMed: 21149577]

53. Ono K, Matsumori A, Shioi T, Furukawa Y, Sasayama S. Cytokine gene expression after myocardial infarction in rat hearts: possible implication in left ventricular remodeling. Circulation. 1998; 98:149-156. [PubMed: 9679721]

54. Ren XP, Wu J, Wang X, Sartor MA, Qian J, Jones K, Nicolaou P, Pritchard TJ, Fan GC. MicroRNA-320 is involved in the regulation of cardiac ischemia/reperfusion injury by targeting heat-shock protein 20. Circulation. 2009; 119:2357-2366. [PubMed: 19380620]

55. Dong S, Cheng Y, Yang J, Li J, Liu X, Wang X, Wang D, Krall TJ, Delphin ES, Zhang C. MicroRNA expression signature and the role of microRNA-21 in the early phase of acute myocardial infarction. J Biol Chem. 2009

56. Xu C, Lu Y, Pan Z, Chu W, Luo X, Lin H, Xiao J, Shan H, Wang Z, Yang B. The muscle-specific microRNAs miR-1 and miR-133 produce opposing effects on apoptosis by targeting HSP60, HSP70 and caspase-9 in cardiomyocytes. J Cell Sci. 2007; 120:3045-3052. [PubMed: 17715156]

57. Shan ZX, Lin QX, Fu YH, Deng CY, Zhou ZL, Zhu JN, Liu XY, Zhang YY, Li Y, Lin SG, et al. Upregulated expression of miR-1/miR-206 in a rat model of myocardial infarction. Biochem Biophys Res Commun. 2009; 381:597-601. [PubMed: 19245789]

58. Rowland RT, Meng X, Cleveland JC, Meldrum DR, Harken AH, Brown JM. Cardioadaptation induced by cyclic ischemic preconditioning is mediated by translational regulation of de novo protein synthesis. J Surg Res. 1997; 71:155-160. [PubMed: 9299284]

59. Murry CE, Jennings RB, Reimer KA. Preconditioning with ischemia: a delay of lethal cell injury in ischemic myocardium. Circulation. 1986; 74:1124-1136. [PubMed: 3769170]

60. Rane S, He M, Sayed D, Vashistha H, Malhotra A, Sadoshima J, Vatner DE, Vatner SF, Abdellatif M. Downregulation of miR-199a derepresses hypoxia-inducible factor-1alpha and Sirtuin 1 and recapitulates hypoxia preconditioning in cardiac myocytes. Circ Res. 2009; 104:879-886. [PubMed: 19265035]

61. Valadi H, Ekstrom K, Bossios A, Sjostrand M, Lee JJ, Lotvall JO. Exosome-mediated transfer of mRNAs and microRNAs is a novel mechanism of genetic exchange between cells. Nat Cell Biol. 2007; 9:654-659. [PubMed: 17486113]

62. Hunter MP, Ismail N, Zhang X, Aguda BD, Lee EJ, Yu L, Xiao T, Schafer J, Lee ML, Schmittgen TD, et al. Detection of microRNA expression in human peripheral blood microvesicles. PLoS One. 2008; 3:e3694. [PubMed: 19002258]

63. Rabinowits G, Gercel-Taylor C, Day JM, Taylor DD, Kloecker GH. Exosomal microRNA: a diagnostic marker for lung cancer. Clin Lung Cancer. 2009; 10:42-46. [PubMed: 19289371]

64. Camussi G, Deregibus MC, Bruno S, Cantaluppi V, Biancone L. Exosomes/microvesicles as a mechanism of cell-to-cell communication. Kidney Int. 2010; 78:838-848. [PubMed: 20703216]

65. Ji X, Takahashi R, Hiura Y, Hirokawa G, Fukushima Y, Iwai N. Plasma miR-208 as a biomarker of myocardial injury. Clin Chem. 2009; 55:1944-1949. [PubMed: 19696117]

66. D’Alessandra Y, Devanna P, Limana F, Straino S, Di Carlo A, Brambilla PG, Rubino M, Carena MC, Spazzafumo L, De Simone M, et al. Circulating microRNAs are new and sensitive biomarkers of myocardial infarction. Eur Heart J. 2010; 31:2765-2773. [PubMed: 20534597]

67. Cheng Y, Tan N, Yang J, Liu X, Cao X, He P, Dong X, Qin S, Zhang C. A translational study of circulating cell-free microRNA-1 in acute myocardial infarction. Clin Sci (Lond). 2010; 119:8795. [PubMed: 20218970]

68. Ai J, Zhang R, Li Y, Pu J, Lu Y, Jiao J, Li K, Yu B, Li Z, Wang R, et al. Circulating microRNA-1 as a potential novel biomarker for acute myocardial infarction. Biochem Biophys Res Commun. 2010; 391:73-77. [PubMed: 19896465]

69. Rossi MA. Pathologic fibrosis and connective tissue matrix in left ventricular hypertrophy due to chronic arterial hypertension in humans. J Hypertens. 1998; 16:1031-1041. [PubMed: 9794745]

70. Swynghedauw B. Molecular mechanisms of myocardial remodeling. Physiol Rev. 1999; 79:215262. [PubMed: 9922372] 
71. Manabe I, Shindo T, Nagai R. Gene expression in fibroblasts and fibrosis: involvement in cardiac hypertrophy. Circ Res. 2002; 91:1103-1113. [PubMed: 12480810]

72. Brown RD, Ambler SK, Mitchell MD, Long CS. The cardiac fibroblast: therapeutic target in myocardial remodeling and failure. Annu Rev Pharmacol Toxicol. 2005; 45:657-687. [PubMed: 15822192]

73. Khan R, Sheppard R. Fibrosis in heart disease: understanding the role of transforming growth factor-beta in cardiomyopathy, valvular disease and arrhythmia. Immunology. 2006; 118:10-24. [PubMed: 16630019]

74. Martos R, Baugh J, Ledwidge M, O’Loughlin C, Conlon C, Patle A, Donnelly SC, McDonald K. Diastolic heart failure: evidence of increased myocardial collagen turnover linked to diastolic dysfunction. Circulation. 2007; 115:888-895. [PubMed: 17283265]

75. van Rooij E, Sutherland LB, Thatcher JE, DiMaio JM, Naseem RH, Marshall WS, Hill JA, Olson EN. Dysregulation of microRNAs after myocardial infarction reveals a role of miR-29 in cardiac fibrosis. Proc Natl Acad Sci U S A. 2008; 105:13027-13032. [PubMed: 18723672]

76. Thum T, Gross C, Fiedler J, Fischer T, Kissler S, Bussen M, Galuppo P, Just S, Rottbauer W, Frantz S, et al. MicroRNA-21 contributes to myocardial disease by stimulating MAP kinase signalling in fibroblasts. Nature. 2008; 456:980-984. [PubMed: 19043405]

77. Roy S, Khanna S, Hussain SR, Biswas S, Azad A, Rink C, Gnyawali S, Shilo S, Nuovo GJ, Sen CK. MicroRNA expression in response to murine myocardial infarction: miR-21 regulates fibroblast metalloprotease-2 via phosphatase and tensin homologue. Cardiovasc Res. 2009; 82:2129. [PubMed: 19147652]

78. Park MJ, Kim MS, Park IC, Kang HS, Yoo H, Park SH, Rhee CH, Hong SI, Lee SH. PTEN suppresses hyaluronic acid-induced matrix metalloproteinase-9 expression in U87MG glioblastoma cells through focal adhesion kinase dephosphorylation. Cancer Res. 2002; 62:63186322. [PubMed: 12414663]

79. Zheng H, Takahashi H, Murai Y, Cui Z, Nomoto K, Niwa H, Tsuneyama K, Takano Y. Expressions of MMP-2, MMP-9 and VEGF are closely linked to growth, invasion, metastasis and angiogenesis of gastric carcinoma. Anticancer Res. 2006; 26:3579-3583. [PubMed: 17094486]

80. Duisters RF, Tijsen AJ, Schroen B, Leenders JJ, Lentink V, van der Made I, Herias V, van Leeuwen RE, Schellings MW, Barenbrug P, et al. miR-133 and miR-30 regulate connective tissue growth factor: implications for a role of microRNAs in myocardial matrix remodeling. Circ Res. 2009; 104:170-178. 176p. following 178. [PubMed: 19096030]

81. Marban E. Cardiac channelopathies. Nature. 2002; 415:213-218. [PubMed: 11805845]

82. Yang B, Lin H, Xiao J, Lu Y, Luo X, Li B, Zhang Y, Xu C, Bai Y, Wang H, et al. The musclespecific microRNA miR-1 regulates cardiac arrhythmogenic potential by targeting GJA1 and KCNJ2. Nat Med. 2007; 13:486-491. [PubMed: 17401374]

83. Jongsma HJ. Diversity of gap junctional proteins: does it play a role in cardiac excitation? J Cardiovasc Electrophysiol. 2000; 11:228-230. [PubMed: 10709720]

84. Saffitz JE, Laing JG, Yamada KA. Connexin expression and turnover: implications for cardiac excitability. Circ Res. 2000; 86:723-728. [PubMed: 10764404]

85. Lerner DL, Yamada KA, Schuessler RB, Saffitz JE. Accelerated onset and increased incidence of ventricular arrhythmias induced by ischemia in Cx43-deficient mice. Circulation. 2000; 101:547552. [PubMed: 10662753]

86. Diaz RJ, Zobel C, Cho HC, Batthish M, Hinek A, Backx PH, Wilson GJ. Selective inhibition of inward rectifier K+ channels (Kir2.1 or Kir2.2) abolishes protection by ischemic preconditioning in rabbit ventricular cardiomyocytes. Circ Res. 2004; 95:325-332. [PubMed: 15231687]

87. Wang Z, Yue L, White M, Pelletier G, Nattel S. Differential distribution of inward rectifier potassium channel transcripts in human atrium versus ventricle. Circulation. 1998; 98:2422-2428. [PubMed: 9832487]

88. Xiao J, Luo X, Lin H, Zhang Y, Lu Y, Wang N, Yang B, Wang Z. MicroRNA miR-133 represses HERG K+ channel expression contributing to QT prolongation in diabetic hearts. J Biol Chem. 2007; 282:12363-12367. [PubMed: 17344217]

89. Luo X, Xiao J, Lin H, Li B, Lu Y, Yang B, Wang Z. Transcriptional activation by stimulating protein 1 and post-transcriptional repression by muscle-specific microRNAs of IKs-encoding 
genes and potential implications in regional heterogeneity of their expressions. J Cell Physiol. 2007; 212:358-367. [PubMed: 17443681]

90. Terentyev D, Belevych AE, Terentyeva R, Martin MM, Malana GE, Kuhn DE, Abdellatif M, Feldman DS, Elton TS, Gyorke S. miR-1 overexpression enhances $\mathrm{Ca}(2+)$ release and promotes cardiac arrhythmogenesis by targeting PP2A regulatory subunit B56alpha and causing CaMKIIdependent hyperphosphorylation of RyR2. Circ Res. 2009; 104:514-521. [PubMed: 19131648]

91. Kuehbacher A, Urbich C, Zeiher AM, Dimmeler S. Role of Dicer and Drosha for endothelial microRNA expression and angiogenesis. Circ Res. 2007; 101:59-68. [PubMed: 17540974]

92. Dews M, Homayouni A, Yu D, Murphy D, Sevignani C, Wentzel E, Furth EE, Lee WM, Enders GH, Mendell JT, et al. Augmentation of tumor angiogenesis by a Myc-activated microRNA cluster. Nat Genet. 2006; 38:1060-1065. [PubMed: 16878133]

93. Wang S, Aurora AB, Johnson BA, Qi X, McAnally J, Hill JA, Richardson JA, Bassel-Duby R, Olson EN. The endothelial-specific microRNA miR-126 governs vascular integrity and angiogenesis. Dev Cell. 2008; 15:261-271. [PubMed: 18694565]

94. Fish JE, Santoro MM, Morton SU, Yu S, Yeh RF, Wythe JD, Ivey KN, Bruneau BG, Stainier DY, Srivastava D. miR-126 regulates angiogenic signaling and vascular integrity. Dev Cell. 2008; 15:272-284. [PubMed: 18694566]

95. Chen Y, Gorski DH. Regulation of angiogenesis through a microRNA (miR-130a) that downregulates antiangiogenic homeobox genes GAX and HOXA5. Blood. 2008; 111:1217-1226. [PubMed: 17957028]

96. Fasanaro P, D’Alessandra Y, Di Stefano V, Melchionna R, Romani S, Pompilio G, Capogrossi MC, Martelli F. MicroRNA-210 modulates endothelial cell response to hypoxia and inhibits the receptor tyrosine kinase ligand Ephrin-A3. J Biol Chem. 2008; 283:15878-15883. [PubMed: 18417479]

97. Lee DY, Deng Z, Wang CH, Yang BB. MicroRNA-378 promotes cell survival, tumor growth, and angiogenesis by targeting SuFu and Fus-1 expression. Proc Natl Acad Sci U S A. 2007; 104:20350-20355. [PubMed: 18077375]

98. Hua Z, Lv Q, Ye W, Wong CK, Cai G, Gu D, Ji Y, Zhao C, Wang J, Yang BB, et al. MiRNAdirected regulation of VEGF and other angiogenic factors under hypoxia. PLoS One. 2006; 1:e116. [PubMed: 17205120]

99. Cimmino A, Calin GA, Fabbri M, Iorio MV, Ferracin M, Shimizu M, Wojcik SE, Aqeilan RI, Zupo S, Dono M, et al. miR-15 and miR-16 induce apoptosis by targeting BCL2. Proc Natl Acad Sci U S A. 2005; 102:13944-13949. [PubMed: 16166262]

100. Bonauer A, Carmona G, Iwasaki M, Mione M, Koyanagi M, Fischer A, Burchfield J, Fox H, Doebele C, Ohtani K, et al. MicroRNA-92a controls angiogenesis and functional recovery of ischemic tissues in mice. Science. 2009; 324:1710-1713. [PubMed: 19460962]

101. Suarez Y, Fernandez-Hernando C, Pober JS, Sessa WC. Dicer dependent microRNAs regulate gene expression and functions in human endothelial cells. Circ Res. 2007; 100:1164-1173. [PubMed: 17379831]

102. Poliseno L, Tuccoli A, Mariani L, Evangelista M, Citti L, Woods K, Mercatanti A, Hammond S, Rainaldi G. MicroRNAs modulate the angiogenic properties of HUVECs. Blood. 2006; 108:3068-3071. [PubMed: 16849646]

103. Ross R. Atherosclerosis--an inflammatory disease. N Engl J Med. 1999; 340:115-126. [PubMed: 9887164]

104. Silvestre JS, Mallat Z, Tedgui A, Levy BI. Post-ischaemic neovascularization and inflammation. Cardiovasc Res. 2008; 78:242-249. [PubMed: 18252762]

105. Harris TA, Yamakuchi M, Ferlito M, Mendell JT, Lowenstein CJ. MicroRNA-126 regulates endothelial expression of vascular cell adhesion molecule 1. Proc Natl Acad Sci U S A. 2008; 105:1516-1521. [PubMed: 18227515]

106. Ji R, Cheng Y, Yue J, Yang J, Liu X, Chen H, Dean DB, Zhang C. MicroRNA expression signature and antisense-mediated depletion reveal an essential role of MicroRNA in vascular neointimal lesion formation. Circ Res. 2007; 100:1579-1588. [PubMed: 17478730] 
107. Liu X, Cheng Y, Zhang S, Lin Y, Yang J, Zhang C. A necessary role of miR-221 and miR-222 in vascular smooth muscle cell proliferation and neointimal hyperplasia. Circ Res. 2009; 104:476487. [PubMed: 19150885]

108. Martin MM, Buckenberger JA, Jiang J, Malana GE, Nuovo GJ, Chotani M, Feldman DS, Schmittgen TD, Elton TS. The human angiotensin II type 1 receptor $+1166 \mathrm{~A} / \mathrm{C}$ polymorphism attenuates microrna-155 binding. J Biol Chem. 2007; 282:24262-24269. [PubMed: 17588946]

109. Bonnardeaux A, Davies E, Jeunemaitre X, Fery I, Charru A, Clauser E, Tiret L, Cambien F, Corvol P, Soubrier F. Angiotensin II type 1 receptor gene polymorphisms in human essential hypertension. Hypertension. 1994; 24:63-69. [PubMed: 8021009]

110. Benetos A, Gautier S, Ricard S, Topouchian J, Asmar R, Poirier O, Larosa E, Guize L, Safar M, Soubrier F, et al. Influence of angiotensin-converting enzyme and angiotensin II type 1 receptor gene polymorphisms on aortic stiffness in normotensive and hypertensive patients. Circulation. 1996; 94:698-703. [PubMed: 8772690]

111. Tiret L, Bonnardeaux A, Poirier O, Ricard S, Marques-Vidal P, Evans A, Arveiler D, Luc G, Kee F, Ducimetiere P, et al. Synergistic effects of angiotensin-converting enzyme and angiotensin-II type 1 receptor gene polymorphisms on risk of myocardial infarction. Lancet. 1994; 344:910913. [PubMed: 7934345]

112. Horie T, Ono K, Nishi H, Iwanaga Y, Nagao K, Kinoshita M, Kuwabara Y, Takanabe R, Hasegawa K, Kita T, et al. MicroRNA-133 regulates the expression of GLUT4 by targeting KLF15 and is involved in metabolic control in cardiac myocytes. Biochem Biophys Res Commun. 2009; 389:315-320. [PubMed: 19720047]

113. Nishi H, Ono K, Iwanaga Y, Horie T, Nagao K, Takemura G, Kinoshita M, Kuwabara Y, Mori RT, Hasegawa K, et al. MicroRNA-15b modulates cellular ATP levels and degenerates mitochondria via Arl2 in neonatal rat cardiac myocytes. J Biol Chem. 2010; 285:4920-4930. [PubMed: 20007690]

114. Horie T, Ono K, Nishi H, Nagao K, Kinoshita M, Watanabe S, Kuwabara Y, Nakashima Y, Takanabe-Mori R, Nishi E, et al. Acute doxorubicin cardiotoxicity is associated with miR-146ainduced inhibition of the neuregulin-ErbB pathway. Cardiovasc Res. 2010; 87:656-664. [PubMed: 20495188]

115. Marquart TJ, Allen RM, Ory DS, Baldan A. miR-33 links SREBP-2 induction to repression of sterol transporters. Proc Natl Acad Sci U S A. 2010; 107:12228-12232. [PubMed: 20566875]

116. Rayner KJ, Suarez Y, Davalos A, Parathath S, Fitzgerald ML, Tamehiro N, Fisher EA, Moore KJ, Fernandez-Hernando C. MiR-33 contributes to the regulation of cholesterol homeostasis. Science. 2010; 328:1570-1573. [PubMed: 20466885]

117. Najafi-Shoushtari SH, Kristo F, Li Y, Shioda T, Cohen DE, Gerszten RE, Naar AM. MicroRNA-33 and the SREBP host genes cooperate to control cholesterol homeostasis. Science. 2010; 328:1566-1569. [PubMed: 20466882]

118. Horie T, Ono K, Horiguchi M, Nishi H, Nakamura T, Nagao K, Kinoshita M, Kuwabara Y, Marusawa H, Iwanaga Y, et al. MicroRNA-33 encoded by an intron of sterol regulatory elementbinding protein 2 (Srebp2) regulates HDL in vivo. Proc Natl Acad Sci U S A. 2010; 107:1732117326. [PubMed: 20855588]

119. Kim JB, Sarraf P, Wright M, Yao KM, Mueller E, Solanes G, Lowell BB, Spiegelman BM. Nutritional and insulin regulation of fatty acid synthetase and leptin gene expression through ADD1/SREBP1. J Clin Invest. 1998; 101:1-9. [PubMed: 9421459]

120. Chen G, Liang G, Ou J, Goldstein JL, Brown MS. Central role for liver X receptor in insulinmediated activation of Srebp-1c transcription and stimulation of fatty acid synthesis in liver. Proc Natl Acad Sci U S A. 2004; 101:11245-11250. [PubMed: 15266058] 


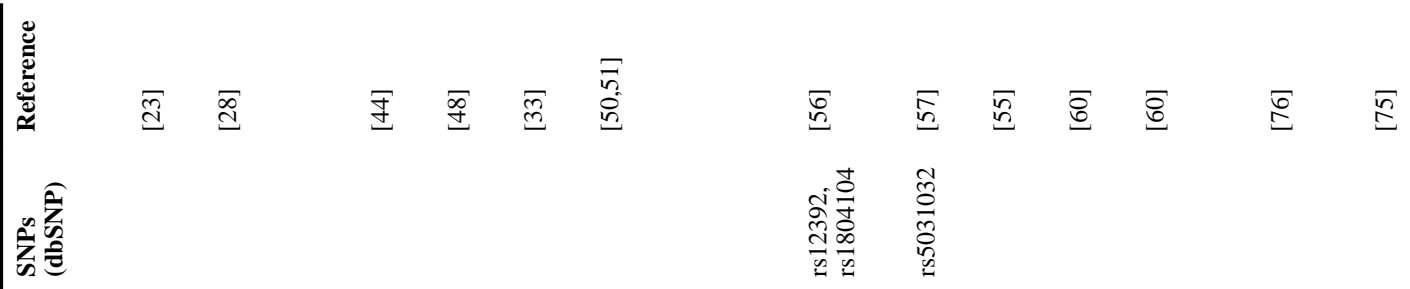

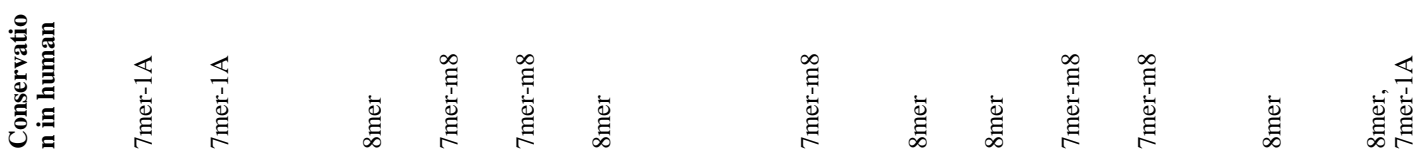

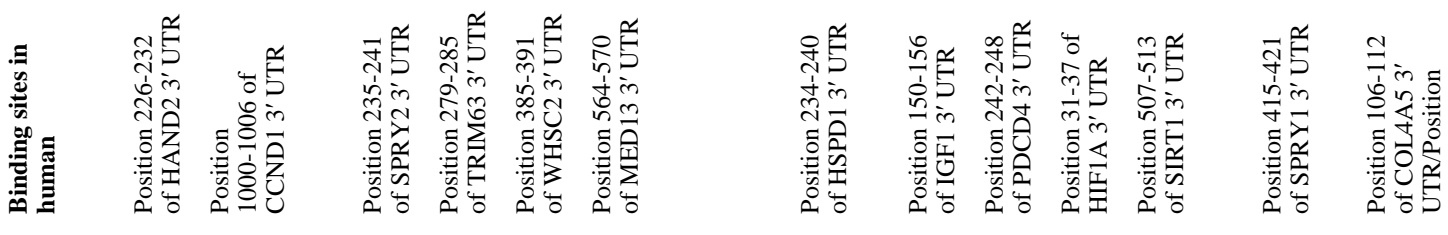

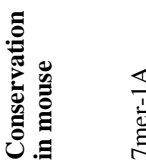

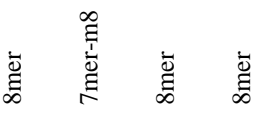

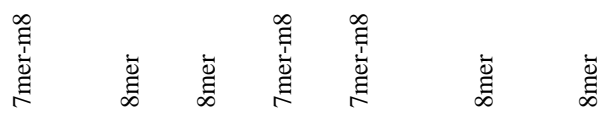




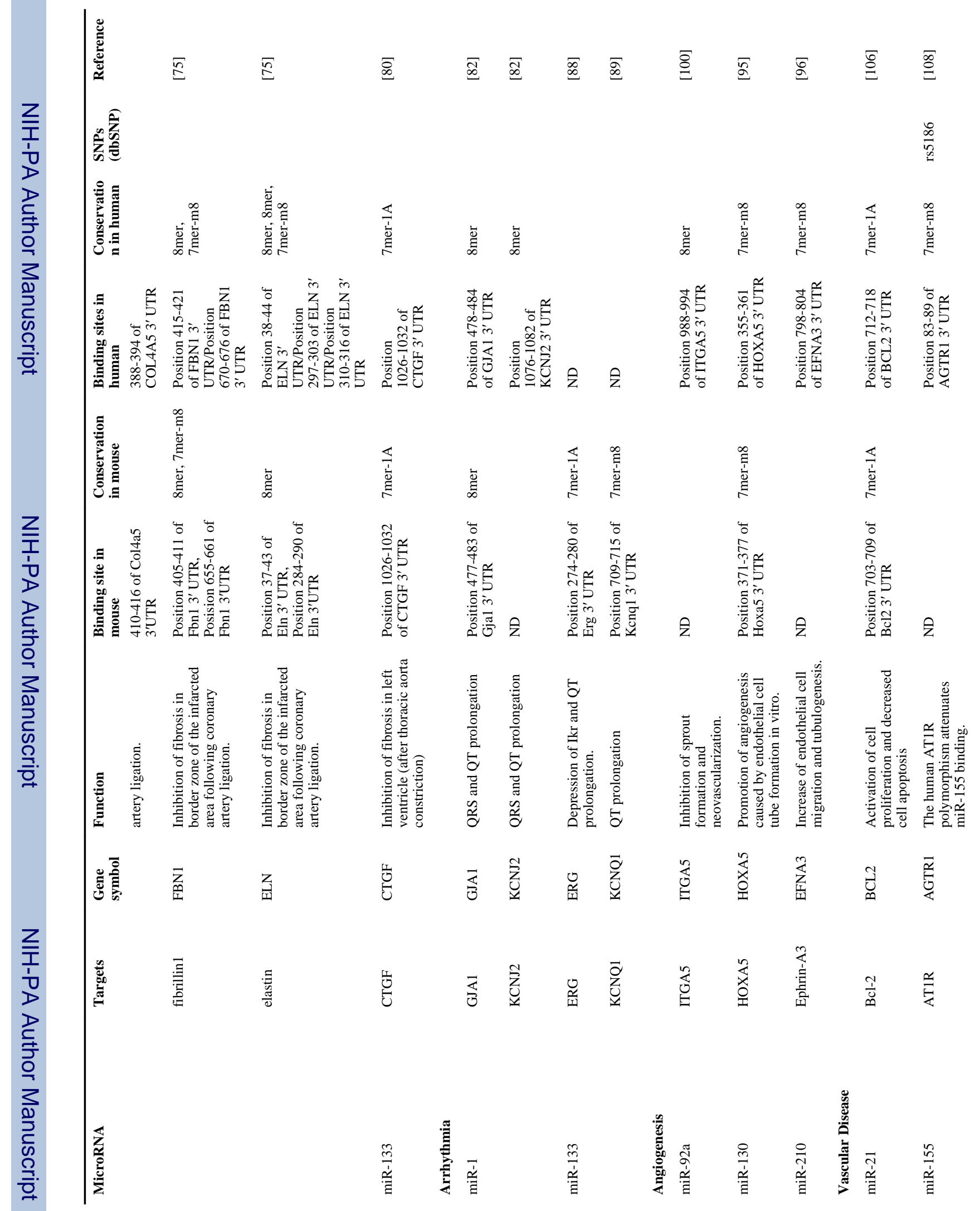


Ono et al.

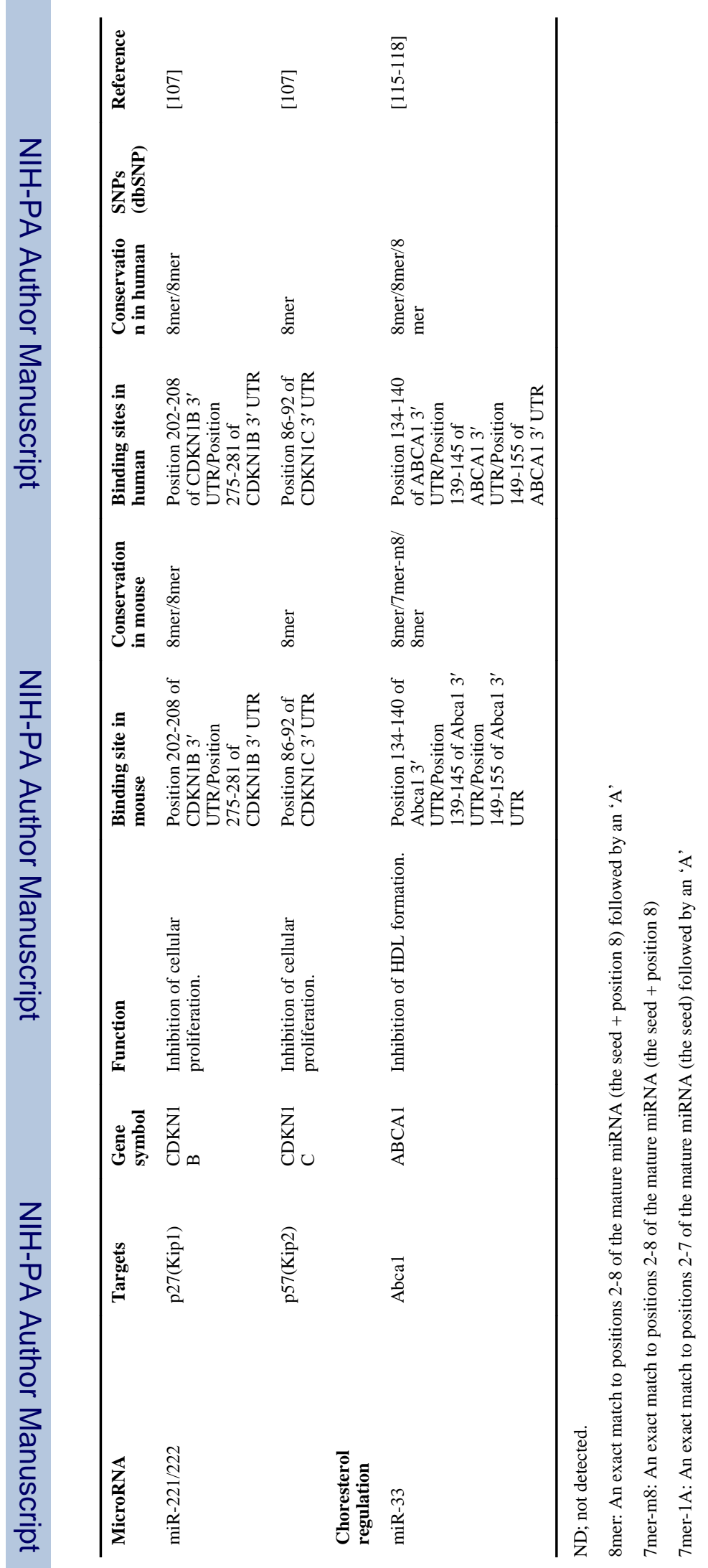

FEBS J. Author manuscript; available in PMC 2012 May 1. 
Table 2

A list of abbreviations

\begin{tabular}{|c|c|}
\hline 3'UTR & 3' untranslated region \\
\hline DGCR8 & DiGeorge syndrome critical region gene 8 \\
\hline MCK & muscle creatine kinase \\
\hline SRF & serum response factor \\
\hline AVC & atrioventricular canal \\
\hline MEF2 & myocyte enhancer factor 2 \\
\hline NFATc3 & nuclear factor of activated $\mathrm{T}$ cells isoform 3 \\
\hline MuRF1 & muscle specific ring finger protein 1 \\
\hline THRAP & thyroid hormone receptor-associated protein \\
\hline MHC & myosin heavy chain \\
\hline MI & myocardial infarction \\
\hline $\mathrm{I} / \mathrm{R}$ & ishcemia and reperfusion \\
\hline HSP & heart shock protein \\
\hline PDCD4 & programmed cell death 4 \\
\hline AP1 & activator protein 1 \\
\hline IGF-1 & insulin-like growth factor-1 \\
\hline HIF & hypoxia inducible factor \\
\hline ECM & extracellular matrix \\
\hline SPRY1 & sprouty homolog 1 \\
\hline ERK-MAPK & extracellular signal-regulated kinase/mitogen-activated protein kinase \\
\hline PTEN & phosphatase and tensin homologue \\
\hline MMP & matrix metalloprotease \\
\hline CTGF & connective tissue growth factor \\
\hline GJA1 & gap junction protein a1 \\
\hline $\mathrm{KCNJ} 2$ & potassium inwardly-rectifying channel, subfamily $\mathrm{J}$, member 2 \\
\hline KCND2 & potassium voltage-gated channel, Shal-related subfamily, member 2 \\
\hline Irx 5 & iroquois homeobox 5 \\
\hline $\mathrm{KCNH} 2$ & potassium voltage-gated channel, subfamily $\mathrm{H}$ (eag-related), member 2 \\
\hline HERG & human ether-à-go-go-related gene \\
\hline KCNQ1 & potassium voltage-gated channel, KQT-like subfamily, member 1 \\
\hline KCNE1 & potassium voltage-gated channel, Isk-related family, member 1 \\
\hline CaMK & $\mathrm{Ca} /$ Calmodulin Kinase \\
\hline RyR2 & ryanodine receptor 2 \\
\hline SR & sarco(endo)plasmic reticulum \\
\hline LDL & low density lipoprotein \\
\hline VCAM-1 & vascular cell adhesion molecule 1 \\
\hline TNF & tumor necrosis factor \\
\hline VSMC & vascular smooth muscle cell \\
\hline AT1R & angiotensin II type 1 receptor \\
\hline SNP & single nucleotide polymorphism \\
\hline
\end{tabular}




\begin{tabular}{ll} 
GLUT4 & glucose transporter 4 \\
KLF15 & Kruppel-like factor-15 \\
CHF & congestive heart failure \\
ABCA1 & ATP-binding cassette transporter A1 \\
SREBP & sterol regulatory element binding protein \\
HDL & high density lipoprotein \\
\hline
\end{tabular}

